\title{
Hubungan Usia Nikah Penggunaan Kontrasepsi Hormonal Dan Personal Hygiene Dengan Kejadian Displasia Serviks Melalui Pemeriksaan Inspeksi Visual Asam Asetat (IVA) Di Puskesmas Bara-Baraya Makassar
}

\author{
The Correlation Of The Marriage Age Hormonal Contraception Use And Personal Hygiene \\ With The Cervikal Dysplasia Incidence Through The Inspection Of Visual Asetat Acid \\ (VAA) In Bara-Baraya Health Center Makassar
}

\author{
Nurhaeda*1 ${ }^{\mathbf{1}}$, Resky Wahyuni ${ }^{2}, \mathrm{~A}$ Wardihan Sinrang ${ }^{3}$, Wema Nontji ${ }^{4}$ \\ ${ }^{*} 1,2$ Akademi Kebidanan Graha Ananda Palu \\ ${ }^{3}$ Bagian Fakultas Kedokteran. Universitas Hasanuddin \\ ${ }^{4}$ Bagian Kebidanan Fakultas Kedokteran Universitas Hasanuddin \\ *Email : edha_yusuf@yahoo.com
}

\begin{abstract}
Abstrak
Di Negara berkembang termasuk Indonesia kanker serviks merupakan penyebab kematian terbanyak dan diperkirakan setiap tahun dijumpai 500.000 penderita baru di seluruh dunia khususnya dinegara berkembang. Tujuan penelitian ini untuk mengetahui hubungan usia nikah, penggunaan kontrasepsi hormonal, dan personal hygiene dengan kejadian displasia serviks melalui pemeriksaan inspeksi visual asam asetat (IVA) di Puskesmas Bara-baraya Makassar. Desain penelitian ini berupa cross sectional. Sampel adalah Ibu yang menggunakan kontrasepsi hormonal sebanyak 62 orang yang diambil secara purposive sampling. Data dianalisis dengan uji Chi Square. Hasil penelitian didapatkan bahwa responden yang usia nikah dini 53 orang (85,5\%), pengunaan kontrasepsi hormonal yang berisiko 46 orang $(74,2)$ dan personal hygiene kurang 59 orang $(95,2 \%)$ sementara usia nikah yang ideal 9 orang $(14,5 \%)$, pengguna kontrasepsi yang tidak berisiko 16 orang $(25,8 \%)$, dan personal Hygiene baik hanya 3 orang $(4,8 \%)$. Berdasarkan hasil uji Chi-Square ada hubungan usia nikah dengan kejadian displasia serviks $(\mathrm{p}=0,002)$. Namun didapatkan tidak ada hubungan penggunaan kontrasepsi hormonal dengan kejadian displasia serviks $(p=0,1000)$. juga tidak ada hubungan antara personal hygiene dengan kejadian displasia serviks $(\mathrm{p}=0,1000)$. Pernikahan pada usia dini $<20$ tahun dengan penggunaan kontrasepsi hormonal $>4$ tahun dan personal hygiene yang kurang dapat memicu terjadianya displasia serviks.
\end{abstract}

Kata Kunci : Usia Nikah, Penggunaan Kontrasepsi Hormonal, Personal Hygiene, Pemeriksaan Inspeksi Visual Asam Asetat (IVA)

\begin{abstract}
In developing countries, including Indonesia, cervical center is the leading cause of death and estimated that each year 500,000 new cases found throunghount the world, especially in developing countries. This research aimed to investigate the correlation of the marriage age, the hormonal contraception use, and the personal hygiene with the cervical dysplasia incidence through the inspection of the visual acetate acid (VVA) in Barbarayya Health Center, Makassar. The research design was crosssectional, and the sampel were the mothers who used hormonal contraception and included 62 mothers chosen using the purposive sampling technique. The data were analyzed using the Chi-Square test. The research results indicated that 53 respondents $(85,5 \%)$ were married at the early ages, 46 respondents $(74,2 \%)$ used risking hormonal contraception, and 59 respondents $(95,2 \%)$ had less personal hygiene, while only 9 respondents $(14,5 \%)$ were married at the ideal ages, 16 respondents $(25,8 \%)$ used risking hormonal contraception, and only 3 respondents (4,8\%) had good personal hygiene. Based on the result of the Chi -square test, there was a correlation between the marriage age and the cervical dysplasia incidence $(p=0,002)$. However, the use of the hormonal contraception had no correlation with the cervical dysplasia $(p=0,1000)$; also the personal hygiene an the servical dysplasia had no correlation with the cervical dysplasia $(p=0,1000)$. The marriage at the early age of $<20$ years and the use of the hormonal contraception were $<4$ years and the inadequate personal hygiene could tigger the incidence of cervical dysplasia.
\end{abstract}

Keywords: Marriage age, use of Hormonal Contraception, personal hygiene, inspection of visual Acetate Acid (VAA) 


\section{PENDAHULUAN}

Di Negara berkembang termasuk Indonesia kanker serviks merupakan penyebab kematian terbanyak dan diperkirakan setiap tahun dijumpai 500.000 [1]. World Health Organization (2013) menemukan 528.000 kasus baru kanker serviks dan 85\% terjadi di daerah yang kurang berkembang [2]. Dan 231.000 jumlah wanita yang meninggal berasal dari negara dengan pendapatan yang rendah, serta 35.000 atau 1 dari 10 wanita berasal dari negara dengan berpendapatan yang tinggi. Amerika Serikat pada tahun 2014 diperkirakan terdapat 12.360 kasus baru kanker serviks dan terjadi 4.020 kematian akibat kanker serviks [3].

Berdasarkan data riset kesehatan tahun 2013 jumlah penderita kanker serviks di Indonesia sebanyak 98.692 kasus [4]. Berdasarkan laporan tahunan dinas provinsi Sulawesi selatan bidan Pengendalian Penyakit Dan Penyehatan Lingkungan (P2PL), jumlah penderita kanker serviks dari tahun ketahun mengalami fluktuasi. Pada tahun 2009 tercatat 1.011 kasus, 1.141 kasus (2010), 210 kasus (2011), 2.066 kasus (2012), dan 536 kasus (2013) [5]. Berdasarkan survailans yang merupakan laporan tahunan penyakit menular untuk kanker serviks baik rawat jalan maupun rawat inap pada tahun 2010 dan 2011 tertinggi di kapupaten enrekang sebanyak 127 kasus, dan Makassar menempati urutan ketiga sebanyak 60 kasus setelah kabupaten Bone sebanyak 25 kasus [6].

Untuk pemecahan masalah tersebut diatas maka perlu dilakukan metode skrining alternative yang mampu mengenali lesi prakanker (displasia). Metode alternative tersebut skrining inspeksi visual asam asetat (IVA) dengan cara mengoleskan asam asetat (cuka) ke dalam leher rahim. Agar pengobatan kanker leher rahim dapat ditangani secara dini [7].

Kebanyakan panduan menganjurkan untuk melakukan skrining pertama dalam waktu 3 tahun pertama setelah aktif secara seksual karena ada beberapa faktor yang menjadi risiko atau secara tidak langsung berpengaruh terhadap pertumbuhan Human Papilloma Virus (HPV) sehingga terjadi lesi prakanker (displasia). Beberapa faktor tersebut adalah status ekonomi, faktor aktivitas seksual yang meliputi usia pertama kali melakukan hubungan seksual, jumlah pasangan seks, multiparitas, kurang menjaga kebersihan genetalia, merokok, riyawat penyakit kelamin dan penggunaan kontrasepsi hormonal jangka panjang [8].

Berdasarkan penelitian yang dilakukan di Bali di Puskesmas Sukada II dengan jumlah sampel 163 pasangan usia subur (PUS) dengan perkawinan $\leq 20$ tahun dengan IVA positif sebanyak 49 orang, sementara penelitian yang dilakukan di puskesmas jati Negara dari 33 responden dengan lesi pra kanker positif sebanyak 32 orang yang artinya kejadian lesi prakanker serviks usia perkawinan $<21$ tahun memiliki risiko lebih besar dari pada usia Perkawinan > 20 tahun untuk mengalami lesi prakanker serviks karena Kanker serviks cenderung timbul bila saat mulai aktif berhubungn seksual pada saat usia kurang dari 17 tahun [9]. Lebih dijelaskan bahwa usia antara 15-20 tahun merupakan periode yang rentan, Epitel serviks pada wanita remaja sangat rentan terhadap bahan-bahan karsinogenikyang ditularkan melalui hubungan seksual dibandingkan dengan epitel serviks wanita dewasa [3] [10].

Hal ini juga sesuai dengan studi yang dilakukan Giambi, yang melakukan penelitian pada sampel dengan usia 18 sampai 26 tahun, ditemukan perbedaan statistik yang bermakna antara wanita yang menikah 
dibawah 21 tahun cenderung untuk terkena kanker serviks di bandingkan wanita yang menikah usia diatas 20 tahun [9]. Khasbiyah dalam penelitiannya, menerangkan terdapat risiko 5,85 kali pada wanita yang melakukan hubungan seksualitas dengan kejadian kanker serviks [11]. Sogukpinar di Izmir, menerangkan hubungan seksual dibawah 20 tahun juga berperan dalam salah satu faktor risiko terjadinya kanker serviks dimana puncak usia pertama kali berhubungan seksualnya adalah 16 tahun [12]. Tujuan penelitian ini untuk mengetahui hubungan usia nikah, penggunaan kontrasepsi hormonal, dan personal hygiene dengan kejadian displasia serviks melalui pemeriksaan inspeksi visual asam asetat (IVA) di Puskesmas Bara-baraya Makassar.

\section{METODE}

Penelitian ini dilakukan di Puskesmas Bara-baraya Makassar. Desain penelitian yang digunakan dalam penelitian ini adalah desain penelitian Analitik dengan pendekatan Cross sectional. Populasi adalah Populasi dalam penelitian ini adalah seluruh pasangan usia subur yang menggunakan kontrasepsi hormonal yang berada diwilayah kerja Puskesmas Bara-Baraya Makassar. Sampel sebanyak 70 orang yang dipilih secara purposive sampling yang telah memenuhi criteria inklusi yaitu, Ibu yang berumur $>30$ Tahun, Bersedia menjadi responden, memiliki anak > 2, menjadi aseptor KB hormonal > 4, dalam keadaan Sehat, tidak haid, 24 jam sebelumnya tidak melakukan hubungan seksual. Analisis berupa analisis univariat dan bivariat merupakan analisa hasil dari variabel-variabel bebas yang diduga mempunyai hubungan dengan variabel terkait. Analisis data yang digunakan adalah uji Chi-Square.

\section{HASIL}

Analisis bivariat dalam penelitian ini menggunakan uji chi square untuk Hubungan Usia Nikah dengan Kejadian Displasia Serviks Melalui Pemeriksaan Inspeksi Visual Asam Asetat (IVA) di Puskesmas Bara-baraya Makassar Tahun 2016 dapat diketahui pada tabel di bawah ini:

Tabel 1. Hubungan Usia Nikah dengan Kejadian Displasia Serviks Melalui Pemeriksaan Inspeksi Visual Asam Asetat (IVA) di Puskesmas Bara-baraya Makassar Tahun 2016

\begin{tabular}{|c|c|c|c|c|c|c|c|}
\hline \multirow[t]{2}{*}{ Variabel } & \multicolumn{2}{|c|}{$\begin{array}{c}\text { Displasia } \\
\text { Serviks Positif }\end{array}$} & \multicolumn{2}{|c|}{$\begin{array}{c}\text { Displasia Serviks } \\
\text { Negatif }\end{array}$} & \multicolumn{2}{|c|}{ Total } & \multirow[t]{2}{*}{ P value } \\
\hline & $\mathbf{n}$ & $\%$ & $\mathbf{n}$ & $\%$ & $\mathbf{n}$ & $\%$ & \\
\hline \multicolumn{7}{|l|}{ Usia Nikah } & \multirow{3}{*}{0.002} \\
\hline Dini & 29 & 54,7 & 24 & 45,3 & 53 & 100 & \\
\hline Ideal & 0 & 0 & 9 & 100 & 9 & 100 & \\
\hline
\end{tabular}

Pada tabel 1 responden yang usia pernikahan dini sebanyak 53 orang dengan hasil negatife sebanyak 24 orang $(45,3 \%)$ dan positif sebanyak 29 orang $(54,7 \%)$ sementara yang usia pernikahan ideal sebanyak 9 orang dengan hasil negatife seluruhnya sebanyak 9 orang (100\%). Hasil analisi uji Chi-Square $(p=0,002)$ sehingga didapatkan $(p<0,05)$ yang artinya ada pengaruh antara usia nikah dengan kejadian displasia serviks.

Analisis bivariat dalam penelitian ini menggunakan uji chi square untuk Penggunaan Kontrasepsi 
Hormonal dengan Kejadian Displasia Serviks Melalui Pemeriksaan Inspeksi Visual Asam Asetat (IVA) di Puskesmas Bara-baraya Makassar Tahun 2016 dapat diketahui pada tabel di bawah ini:

Tabel 2. Hubungan Penggunaan Kontrasepsi Hormonal dengan Kejadian Displasia Serviks Melalui Pemeriksaan Inspeksi Visual Asam Asetat (IVA) di Puskesmas Bara-baraya Makassar Tahun 2016

\begin{tabular}{|c|c|c|c|c|c|c|c|}
\hline \multirow[t]{2}{*}{ Variabel } & \multicolumn{2}{|c|}{$\begin{array}{c}\text { Displasia } \\
\text { Serviks Positif } \\
\end{array}$} & \multicolumn{2}{|c|}{$\begin{array}{c}\text { Displasia } \\
\text { Serviks Negatif } \\
\end{array}$} & \multicolumn{2}{|c|}{ Total } & \multirow[t]{2}{*}{ Pvalue } \\
\hline & $\mathbf{n}$ & $\%$ & $\mathbf{n}$ & $\%$ & $\mathbf{n}$ & $\%$ & \\
\hline \multicolumn{7}{|l|}{$\begin{array}{l}\text { Penggunaan Kon- } \\
\text { trasepsi }\end{array}$} & \multirow{3}{*}{0.1000} \\
\hline Berisiko & 22 & 47,8 & 24 & 52,2 & 46 & 100 & \\
\hline Tidak Berisiko & 7 & 43,8 & 9 & 56,3 & 16 & 100 & \\
\hline
\end{tabular}

Pada tabel 2 responden yang beresiko sebanyak 46 orang dengan hasil displasia negatif sebanyak 24 orang $(52,2 \%)$ dan positif sebanyak 22 orang $(47,8 \%)$. Sementara yang tidak berisiko dengan hasil displasia negatife sebanyak 9 orang $(56,3 \%)$ dan positif 7 orang $(43,8 \%)$. Hasil analisis uji Chi-Square $(p=0,1000)$ sehingga didapatkan bahwa $p>0,05$ yang artinya tidak ada pengaruh antara lama menggunakan kontrasepsi hormonal dengan kejadian displasia serviks.

Analisis bivariat dalam penelitian ini menggunakan uji chi square untuk Personal Hygiene dengan Kejadian Displasia Serviks Melalui Pemeriksaan Inspeksi Visual Asam Asetat (IVA) di Puskesmas Bara-baraya Makassar Tahun 2016 dapat diketahui pada tabel di bawah ini:

Tabel 3. Hubungan Personal Hygiene dengan Kejadian Displasia Serviks Melalui Pemeriksaan Inspeksi Visual Asam Asetat (IVA) di Puskesmas Bara-baraya Makassar Tahun 2016

\begin{tabular}{|c|c|c|c|c|c|c|c|}
\hline \multirow{3}{*}{ Variabel } & \multirow{2}{*}{\multicolumn{2}{|c|}{$\begin{array}{c}\text { Displasia } \\
\text { Serviks Positif } \\
\end{array}$}} & \multirow{2}{*}{\multicolumn{2}{|c|}{$\begin{array}{c}\text { Displasia } \\
\text { Serviks Negatif }\end{array}$}} & \multirow{2}{*}{\multicolumn{2}{|c|}{ Total }} & \multirow{3}{*}{ Pvalue } \\
\hline & & & & & & & \\
\hline & $\mathbf{n}$ & $\%$ & $\mathbf{n}$ & $\%$ & $\mathbf{n}$ & $\%$ & \\
\hline \multicolumn{7}{|c|}{ Personal Hygiene } & \multirow{3}{*}{0.1000} \\
\hline Baik & 1 & 33,3 & 2 & 66,7 & 3 & 100 & \\
\hline Kurang & 29 & 46,8 & 31 & 52,5 & 59 & 100 & \\
\hline
\end{tabular}

Pada tabel 3 responden dengan personal hygiene yang baik sebanyak 33 orang dengan hasil displasia negatif sebanyak 2 orang (66,7\%), dan positif sebanyak 1 orang (33,3\%) sementara personal hygiene kurang sebanyak 59 dengan hasil negatif sebanyak 31 orang (52,5\%) dan positif sebanyak 29 (46,8\%). Hasil analisis statistic uji Chi-Square $(p=0,1000)$ sehingga didapatkan nilai $(p>0,05)$ yang artinya tidak ada hubungan antara personal hygiene dengan kejadian displasia serviks.

\section{PEMBAHASAN}


Hasil penelitian didapatkan bahwa ada hubungan antara usia nikah dengan kejadian displasia serviks diperoleh nilai $p=0,002(p<0,05)$, namun penelitian ini didapatkan usia dini $(\leq 20$ tahun) yang terdeteksi displasia positif sebanyak 29 orang (54,7\%). Berdasarkan teori Colditz (2004) \& Rasjidi (2008), Umur saat perkawinan $\leq 20$ tahun erat kaitanya dengan aktivitas seksual, hubungan seksual yang dilakukan terlalu dini dapat mempengaruhi pada kerusakan jaringan epitel serviks atau dinding rongga vagina [13] [14]. Kondisi tersebut dapat bertambah buruk mengarah pada kelainan sel dan pertumbuhan abnormal, wanita yang melakukan hubungan seksual secara aktif sejak sebelum 17 tahun memiliki potensi 3 kali lebih besar untuk menghidap kanker serviks dibandingkan wanita yang tidak melakukan hubungan seksual pada usia tersebut. Hal ini terjadi karena pada umur tersebut sel-sel pada mulut rahim belum matang dan rentang terhadap infeksi dan mutasi [13]. Hubungan seksual pada umur di bawah 17 tahun merangsang tumbuhnya sel pada alat kandungan perempuan, pada rentang umur 12-17 tahun perubahan sel dalam mulut rahim lebih aktif. Ketika sel sedang membelah secara aktif (metaplasia). Metaplasia epitel skuamosa biasanya merupakan proses fisiologis. Tetapi dibawah pengaruh karsinogenik, perubahan sel dapat terjadi sehingga mengakibatkan suatu zona trasformasi yang patologik. Perubahan yang tidak khas ini menginisiasi suatu proses yang disebut Neoplasia Intraepitel Serviks (NIS) atau lesi prakanker yang merupakan fase prainvasif kanker serviks [15].

Sementara hubungan penggunaan kontrasepsi hormonal dengan kejadian displasia serviks di Puskesmas Bara-baraya Makassar nilai $p$ value $=0,1000(p>0,05)$ Hasil penelitian ini sejalan dengan penelitian yang dilakukan oleh Irmayani (2013), Dengan hasil menunjukkan bahwa tidak ada hubungan penggunaan kontrasepsi dengan kejadian lesi prakanker dengan hasil uji Chi Square nilai $p=0,547$ (nilai $p>0,05$ ) [16].

Hasil penelitian diatas tidak sesuai dengan penelitian yang dilakukan oleh Wahyuninigsih \& Erry (2014), dengan judul Faktor Risiko terjadinya Prakanker serviks melalui Deteksi Dini dengan Metode Inspeksi Visual Asam Asetat. yang menyatakan ada hubungan yang signifikan antara penggunaan kontrasepsi hormonal dengan kejadian displasia serviks dan hasil peneliti tidak memiliki hubungan karena yang berisiko lebih besar negative $52,2 \%$ terjadinya displasia dibandingkan dengan yang positif sebanyak $47,8 \%$ [17].

Penggunaan jangka panjang $>4$ tahun dari kontarasepsi hormonal dipercaya berhubungan dengan peningkatan risiko kanker serviks. Semakin lama seseorang menggunakan kontrasepsi hormonal semakin tinggi risiko untuk mendapatkan kanker serviks. Hormon yang terkandung pada kontrasepsi hormonal dapat mengubah kepekaan sel serviks [18]. Akan tetapi resikonya tersebut akan turun kembali setelah kontrasepsi hormonal dihentikan. Resiko kembali normal setelah 5 sampai 10 tahun setelah mereka hentikan [19].

Sementara hubungan personal hygiene dengan kejadian displasia serviks di Puskesmas Bara-baraya Makassar dengan nilai $p=1,000(p>0,05)$ ini menunjukkan bahwa tidak ada hubungan personal hygiene dengan kejadian displasia serviks.

Hasil penelitian ini sejalan dengan penelitian yang dilakukan oleh Ridhaningsih \& Nurjannah (2010), dimana penggunaan antiseptik dan deodorant, pembalut/pentiliner dan cara cebok tidak ada hubungannya dengan kejadian prakanker (displasia). 
Personal hygiene dilakukan dengan menggunakan sabun yang rutin akan mengiritasi mukus sekitar vagina sehingga memudahkan kuman dan bakteri tumbuh dan berkembanya dan menyebabkan terjadinya displasia. sedangkan pemakain sabun antiseptik akan membunuh semua bakteri, pemakain pembalut yang bersentuhan dengan kulit, jika hanya diganti 2 kali atau kurang dapat menyebabkan kelembaban berlebihan yang memudahkan pertumbuhan jamur dan bakteri [20].

Menurut Ridhaningsih \& Nurjannah (2010), hal tersebut dapat berubah dikarenakan bila seseorang memiliki daya tahan tubuh yang kuat maka tubuh akan dapat melawan virus, bakteri, dan jamur, sehingga vagina dalam keadaan sehat memproduksi cairan yang bening, tidak berbau, tidak berwarna, dalam jumlah yang tidak berlebihan, dan sedikit licin. Fungsi dari cairan ini adalah untuk melindungi vagina dari gesekan antara dinding vagina pada saat beraktivitas. Selain itu pada vagina juga terdapat bakteri yang dibutuhkan oleh vagina yang berfungsi menjaga keseimbangan ekosistem vagina [21].

\section{KESIMPULAN DAN SARAN}

Usia nikah berhubungan dengan kejadian displasia serviks. penggunaan kontrasepsi hormonal tidak berhubungan dengan kejadian displasia serviks, personal hygiene tidak berhubungan dengan kejadian displasia serviks. Pernikahan usia dini ( $<20$ tahun), penggunaan kontrasepsi hormonal dan personal hygiene yang kurang baik berisiko terjadinya displasia serviks.

\section{DAFTAR PUSTAKA}

[1] Depkes R. I., "KepMenKes RI Nomor 796/Menkes/SKVIII/2012. Tentang Pedoman Teknis Pengendalian Kanker Payudara dan Kanker Leher Rahim.," 2012. [Online]. Available: www.hukor.depkes.go.id. [Accessed: 28-Dec-2015].

[2] World Health Organization, "Buletin Of The World Organization 2012," 2013. [Online]. Available: www.exara.com. [Accessed: 28-Dec-2015].

[3] American Cancer Society, "Cervical cancer causes, risk factors and prevention topics," 2012. [Online]. Available: http://www.cancer.org/Cancer/CervicalCancer/DetailedGuide/cervical-cancer-risk-factors. [Accessed: 28-Jul-2016].

[4] Pusat Data \& Informasi R. I, Stop Kanker. Sulawesi Selatan: Departemen Kesehatan, 2015.

[5] Dinkes Sulawesi Selatan, "Laporan Tahunan Sub. Bagian Pengamatan Penyakit Tidak Menular Sulawesi Selatan,” Makassar, 2013.

[6] S. I. S. K. MAKASSSAR, "POLA PENCARIAN PENGOBATAN PADA PENDERITA KANKER SERVIKS DI RUMAH SAKIT LABUANG BAJI DAN RUMAH."

[7] N. ari Pangesti and others, "Gambaran Karakteristik Wanita Usia Subur (WUS) yang Melakukan Pemeriksaan Inspeksi Visual Asam Asetat (IVA) di Puskesmas Karanganyar," J. Ilm. Kesehat. Keperawatan, vol. 8, no. 2, 2012.

[8] H. G. S. A. Putra and I. G. P. M. Mayura, "PREVALENSI DAN KARAKTERISTIK PELAYANAN VAKSINASI CERVARIX SEBAGAI PREVENSI PRIMER KANKER SERVIKS DI SMP NEGERI 1 DENPASAR PERIODE OKTOBER 2011-APRIL 2012," E-Jurnal Med. Udayana.

[9] C. Giambi et al., "A cross-sectional study to estimate high-risk human papillomavirus prevalence and type distribution in Italian women aged 18--26 years," BMC Infect. Dis., vol. 13, no. 1, p. 74, 2013.

[10] M. A. De Boer et al., "Human papillomavirus type 18 and other risk factors for cervical cancer in Jakarta, Indonesia," Int. J. Gynecol. Cancer, vol. 16, no. 5, pp. 1809-1814, 2006. 
[11] K. KHASBIYAH, "BEBERAPA FAKTOR RISIKO KANKER SERVIKS UTERI (Studi Pada Penderita Kanker Serviks Uteri Di Rumah Sakit Dokter Kariadi Semarang Pada Bulan Agustus-September 2004)," Diponegoro University, 2004.

[12] N. Sogukp \inar et al., "Assessment of cervical cancer risk in women between 15 and 49 years of age: case of Izmir," Asian Pacific J. Cancer Prev., vol. 14, no. 3, pp. 2119-2125, 2013.

[13] Colditz G, Handbook Of Cancer Assesment and Prevention. United States of America: Jones and Bartlet Publisher inc., 2004.

[14] R. I, Modalitas Deteksi Dini Kanker Serviks. Jakarta: Sagung Seto, 2008.

[15] R. CB and M. L, Obstetri dan Ginekologi, 9th ed. Jakarta: ECG, 2009.

[16] I. Irmayani, "FAKTOR RESIKO YANG BERHUBUNGAN DENGAN LESI PRAKANKER SERVIKS PADA WPS TIDAK LANGSUNG DI WILAYAH KERJA PUSKESMAS MENINTING," J. Kesehat. Prima, vol. 8, no. 2, pp. 1279-1291, 2018.

[17] T. Wahyuningsih and E. Y. Mulyani, "Faktor risiko terjadinya lesi prakanker serviks melalui deteksi dini dengan metode IVA (inspeksi visual dengan asam asetat)," in Forum ilmiah, 2014, vol. 11, no. 2, pp. 192 $-209$.

[18] J. Monsonego, H. Magdelenat, F. Catalan, Y. Coscas, L. Zerat, and X. Sastre, "Estrogen and progesterone receptors in cervical human papillomavirus related lesions," Int. J. cancer, vol. 48, no. 4, pp. 533-539, 1991.

[19] Malva, "Faktor yang mempengaruhi kejadian kanker serviks leher rahim pada penderita yang dating berobat di RSUP H. Adam Malik Medan Universitas Sumatra Utara," 2008. [Online]. Available: http:// repository.usu.ac.id/bitstreant12345678/6778/1/09Goo80.pdf. [Accessed: 20-Jun-2016].

[20] P. S and Dkk, Ilmu Kebidanan. Jakarta: Yayasan Bina Pustaka Sarwono Prawirohardjo, 2001.

[21] R. Ridhaningsih and S. N. Djannah, "Hubungan Aktivitas Seksual pada Usia Dini, Promiskuitas dan Bilas Vagina dengan Kejadian Kanker Leher Rahim pada Pasien Onkology di RSUD Dr. moewardi Surakarta," Kes Mas J. Fak. Kesehat. Masy. Univ. Ahmad Daulan, vol. 5, no. 2, 2011. 